\title{
The Global Domain of the Dollar: Eight Questions
}

\author{
Robert N. McCauley ${ }^{1}$
}

Accepted: 9 December 2020/ Published online: 28 January 2021

(C) The Author(s) 2021

\begin{abstract}
Since the late 1950s, the rest of the world has come to use the dollar to an extent that justifies speaking of the dollar's global domain. The rest of the world denominates much debt in U.S. dollars, extending U.S. monetary policy's sway. In addition, in outstanding foreign exchange deals, the rest of the world has undertaken to pay still more in U.S. dollars: off-balance-sheet dollar debts buried in footnotes. Consistent with the scale of dollar debt, most of the world economic activity takes place in countries with currencies tied to or relatively stable against the dollar, forming a dollar zone much larger than the euro zone. Even though the dollar assets of the world (minus the United States) exceed dollar liabilities, corporate sector dollar debts seem to make dollar appreciation akin to a global tightening of credit. Since the 1960s, claims that the dollar's global role suffers from instability and confers great benefits on the U.S. economy have attracted much support. However, evidence that demand for dollars from official reserve managers forces unsustainable U.S. current account or fiscal deficits is not strong. The so-called exorbitant privilege is small or shared. In 2008 and again in 2020, the Federal Reserve demonstrated a willingness and capacity to backstop the global domain of the dollar. Politics could constrain the Fed's ability to backstop the growing share of the domain of the dollar accounted for by countries that are not on such friendly terms with the U.S.
\end{abstract}

Keywords International monetary system $\cdot$ Dollar dominance $\cdot$ Eurodollar market $\cdot$ Triffin dilemma $\cdot$ Exorbitant privilege $\cdot$ International borrowing $\cdot$ Foreign exchange market $\cdot$ International lender of last resort

JEL $\quad \mathrm{E} 42 \cdot \mathrm{E} 44 \cdot \mathrm{F} 3 \cdot \mathrm{F} 55 \cdot \mathrm{G} 15 \cdot \mathrm{G} 28$

Robert N. McCauley

robertneilmccauley@gmail.com

1 Nonresident Senior Fellow, Global Development Policy Center, Boston University, Boston, MA and Senior Research Associate, The Global History of Capitalism project, Oxford Centre for Global History, University of Oxford, Oxford, UK 


\section{Introduction}

In the late 1950s, the U.S. dollar began to extend its domain. First came bank accounts in London (Schenk 1998), then Eurobonds issued by firms and governments (O'Malley 2015). U.S. policy, including interest rate caps, reserve requirements and deposit insurance on domestic bank accounts, and even controls on capital outflows all pushed dollar intermediation offshore (Aliber 1980, 2016).

Today, banks and investors hold $\$ 12$ trillion of claims on borrowers outside the U.S. These borrowers owe a like amount arising from off-balance-sheet commitments to buy dollars against foreign currencies. Half or more of the world economy lies in a dollar zone defined by having a currency more stable against the dollar than against the euro or other key currency. Oddly enough, dollar depreciation eases global credit conditions even as the rest of the world loses wealth on net.

From the late 1950s, influential voices have argued that the dollar's global role suffers from inherent instability. Triffin (1960) argued that the world's need for dollars would either cripple trade or unhinge the dollar from gold in the era of fixed exchange rates. Later, after the dollar floated against major currencies, (Volcker and Feldstein 2013) and many others ascribed unsustainable U.S. current account deficits to the global demand for dollars. Most recently, Fahri et al. (2011) and Caballero et al. (2017) worried that the demand for safe assets would either encounter a crippling shortage or would lead the U.S. Treasury to over-borrow. Against these voices, Kindleberger (1965), McKinnon (1969) and Bordo and McCauley (2019) argued that there was no inherent instability in the dollar's role.

A related question is whether the dollar's broad use confers an exorbitant privilege on the U.S. economy, as alleged in France in the 1960s (Eichengreen 2011). Those who see the dollar's role as unstable tend to see it as lucrative so that fairness joins necessity in pointing to change.

This brief overview paper contends that the global role of the dollar remains large and suffers from neither economic instability nor unacceptable privilege. The triple coincidence of the gross domestic product (GDP) area, maximizing agents and a single currency's use does not hold (Avdjiev et al., 2016). In particular, since the dollar's domain does not coincide with the U.S. economy, the rest of the world can supply itself with dollars and benefit from any favorable financing opportunities in the dollar.

The global domain of the dollar has changed both the effect and operation of U.S. monetary policy. Offshore dollar debts and the dollar zone give the Fed's policy often overlooked power, directly and indirectly, to alter monetary conditions globally. Offshore dollar debt imparts to movements in the dollar some surprising effects. Dollar depreciation can make dollar borrowers more creditworthy and ease the supply of credit to them. In 2008 and 2020, the Fed found reason within its domestic mandate to extend dollar credit abroad freely when dollar funding markets seized up and thereby extended its backstop to the dollar's global domain. Looking forward, political forces, not economic forces, constrain this backstop.

The rest of this paper poses and answers eight questions. The first four concern the domain and economics of global dollar markets: banking, bond and foreign 
exchange. The fifth and sixth address widely held views, arguably myths, that the dollar's international role is inherently unstable and is lucrative to the U.S. economy. The seventh and eighth deal with macro policy: The Federal Reserve's capacity to backstop the global domain of the dollar.

\section{Markets: How Many Dollars Does the Rest of the World Owe?}

Nonbanks outside the U.S. carried $\$ 12.7$ trillion in dollar debt, or about $18 \%$ of the rest of the world's GDP in 2019 (Bank for International Settlements 2020; updating Borio et al., 2011). Offshore dollar banking now amounts to about half of the U.S. total; the offshore dollar bond market amounts to a smaller fraction of its (non-U.S. Treasury) U.S. counterpart. With the exception of the early 2000s, Eurodollar markets have mostly intermediated between non-U.S. investors and non-U.S. borrowers (He and McCauley, 2012). The implication is that the rest of the world does not depend solely on the U.S. economy to produce U.S. dollar assets to hold. Dollar borrowing by the rest of the world supplies dollar assets to the rest of the world.

Offshore dollar debt enhances the effect of U.S. monetary policy. The Fed's lowering the federal funds rate immediately boosts cash flows for non-U.S. firms with dollar debt carrying floating interest rates. The Fed's efforts to lower U.S. bond yields after 2009 had the unintended effect of the offshore dollar bond market outgrowing its U.S. counterpart (McCauley et al., 2015; McCauley 2017).

\section{Markets: Is There More Hidden or Generally Overlooked Dollar Debt Offshore?}

The answer is yes, over $\$ 10$ trillion, which is about as much as on the balance sheets of firms and governments outside the U.S. (Borio et al., 2017). In forward foreign exchange deals, non-U.S. firms and investors have undertaken to deliver dollars against other currencies at future dates in such large amounts. Some reflect the wide use of the dollar to invoice international trade (Gopinath and Stein, 2018), as foreign firms hedge dollar cash receipts into domestic currency. However, most reflect the way that global investors reconcile their desired holdings of dollar-denominated bonds and U.S. equities with their smaller desired exposure to the dollar, as such investors sell dollars forward against domestic currency.

The rest of the world's investors generally hedge their dollar-denominated bonds and U.S. equities by rolling over short-term hedges, creating a maturity mismatch. ${ }^{1}$ In calm markets, huge rollovers leave little trace. However, in the strained markets of 2008-09 and 2020, banks and others limited arbitrage transactions. Dollar interest rates in forward exchange markets rose above U.S. dollar money market rates

\footnotetext{
1 Non-U.S. banks also raise dollars through foreign exchange swaps and forwards, though bank supervisors may limit maturity mismatches (Aldasoro et al., 2020).
} 
(Borio et al., 2016). In effect, dollar interest rates rose in the offshore domain of the dollar, autonomously tightening credit conditions. The Fed's cooperation with major central banks to lend dollars globally has proven effective in making dollar interest rates more uniform across the domain of the dollar (Goldberg et al., 2010; Bahaj and Reis, 2018, 2020; Tooze 2018; McCauley and Schenk, 2020; see the two macro policy sections).

\section{Markets: How Big is the Dollar Zone?}

The dollar zone is half or more of the global economy. The share of the dollar zone, defined as economies whose currencies vary less against the dollar than against the euro or other key currencies, has remained at 50-60\% of world GDP (Ito and McCauley, 2019). This result is robust to the choice of method for determining in which zone a given currency places the home country (Ilzetzki et al., 2019). While the dollar zone has shrunk geographically as the line between the euro and dollar has moved east in Europe, faster growth in more dollar-linked Asia has maintained the dollar share.

The relative stability of the dollar exchange rate bears a strong positive relationship (with causation running both ways) to the dollar share of trade invoicing, international debts and official foreign exchange reserves (Aliber 1982; Gopinath and Stein, 2018; Ito and McCauley, 2020). A big question is how the renminbi (RMB) will relate to the dollar and euro (McCauley and Shu, 2019). While inertia may favor the dollar, key currencies can gain ground quickly (Eichengreen and Flandreau, 2009, 2010; Eichengreen et al., 2019).

\section{Markets: Is the Rest of the World Short the Dollar?}

The rest of the world is in aggregate long the dollar in the sense of having dollar claims on the U.S. in excess of dollar liabilities to the U.S. The net has reached over $100 \%$ of U.S. GDP. Therefore, in aggregate, dollar depreciation must inflict wealth losses on the world minus the U.S. (Tille 2003; Gourinchas and Rey, 2007, 2014; Bénétrix et al., 2015; McCauley 2015) and confer wealth gains on the U.S. Some characterize this effect as automatic U.S. debt relief from dollar depreciation.

However, the corporate sector in many countries has taken on substantial dollar debt, much of which does not hedge dollar cash flows or assets. As a result, dollar depreciation reduces corporate leverage and eases the supply of bank and bond credit to non-U.S. firms. Conversely, dollar appreciation acts like a global tightening of credit terms. Empirical analyses find that dollar depreciation actually stimulates investment by dollar-indebted non-U.S. firms and boosts activity (Avdjiev et al., 2019; Burcu et al., 2020). The world minus the U.S. must lose from dollar depreciation but it acts like it gains, as if it had a short position in the dollar.

How can the aggregate long dollar position be reconciled with such behavior? The long U.S. dollar position of the rest of the world's public sector (i.e., the excess of official foreign exchange reserves denominated in the dollar over dollar liabilities 
of the sector) means that its wealth rises when the dollar appreciates. This need not lead to expansive fiscal policy or transfers to dollar-indebted corporations. Firms with unhedged dollar liabilities, in contrast, are constrained by deteriorating balance sheets and less accommodating creditors to respond to dollar appreciation. Thus, what is true of the whole is not true of the (behaviorally salient) parts: the fallacy of division.

\section{Myths: Does Global Demand for Dollars Impose Dilemmas?}

The answer is no. The evidence is weak for the proposition that satisfying the demand by official reserve managers for dollar assets has made the U.S. current account or fiscal deficit unsustainable (Bordo and McCauley, 2019). Larger dollar reserve accumulation has not been associated with unusually wide unexplained U.S. current account deficits. Moreover, U.S. current accounts have cumulated into a substantial foreign debt (strictly speaking net international investment liabilities), but the U.S. economy is still not making net international investment payments. Thus, in the absence of spiraling external debt service, the unsustainability of the U.S. external position is not obvious. Regarding dollar safe assets, the U.S. Treasury does not have a monopoly on producing them (McCauley 2020b). Moreover, the idea that the demand for safe assets is allowing or requiring U.S. fiscal deficits is inconsistent with the last five years of data. Official foreign exchange reserves did not grow in 2014-2019, but the U.S. fiscal deficit exploded.

\section{Myths: Does the Dollar Confer an Exorbitant Privilege?}

The answer is no. Many hold that the U.S. economy benefits big time from the global role of the dollar (Eichengreen 2011; Prasad 2014; Farhi and Maggiori, 2018). On closer examination, the pecuniary benefits are small or so widely shared as to not qualify as a privilege (McCauley 2015). Offshore holdings of dollar bills benefit as an interest-free loan, but such benefit is macroeconomically small and shared with the euro area. The U.S. borrows in its own currency, but so do other advanced economy debtor countries. The U.S. Treasury may borrow more cheaply owing to official holdings, but the rest of the world shares in this advantage. Indeed, the U.S. Treasury has no monopoly in providing even U.S. dollar reserve assets (Farhi and Maggiori, 2018; McCauley 2020b). U.S. external assets yield more than U.S. external liabilities, but this undoubted advantage arises from foreign firms' adverse selection in, overpayment for and eventual losses on U.S. direct investment (Laster and McCauley, 1994), not from the dollar's international role. U.S. banks may benefit from playing on the home court (i.e., the dollar), but they have in fact won a modest share of offshore dollar banking (Swoboda 1968; McCauley 2015).

If pecuniary benefits are limited, then the dollar's international role cannot provide large net benefits to the U.S. economy (Aliber 1964; Cohen 2012), unless one places a large value on the dollar's use (weaponization) for non-pecuniary 
purposes like enforcing U.S. sanctions. Limits to such use are suggested by U.S. allies' consideration of payment arrangements to skirt the dollar's domain (European Commission 2019; Eichengreen and Gros, 2020).

\section{Macro Policy: Is the Domain of the Dollar Getting Too Big for the Fed to Backstop?}

The answer is no. Foulis (2015) suggested that an offshore dollar market that grows with the world economy would outgrow the Fed's ability to backstop it, which is grounded in the slower-growing U.S. economy. However, with precedents in the 1960s (McCauley and Schenk, 2020), the Fed proved in 2008 and 2020 that it can expand credit as necessary to backstop dollar-indebted nonU.S. banks (Baba et al., 2009). In particular, it swapped dollars for the currencies of major central banks to allow them in turn to provide dollars to banks headquartered outside the U.S. The Fed swapped with major central banks without pre-set limits, dropping the linkage to possible International Monetary Fund (IMF) credit (Aliber and Kindleberger, 2015, p 303).

In 2008, swaps succeeded in bringing down the offshore dollar rate, Libor, a critical link in the transmission of the Fed's policy rate cuts to U.S. corporate and adjustable-rate mortgage borrowers (Goldberg et al., 2010; McCauley and Schenk, 2020). It also brought down dollar interest rate premia in forward exchange markets (Goldberg et al., 2010; Bahaj and Reis, 2018, 2020; Avdjiev et al., 2020; Aldosoro et al., 2020). In 2020, non-U.S. dollar bond issuers benefitted from the Fed's buying U.S. corporate bonds (McCauley 2020a). The Fed's backstop of the domain of the dollar extended out the yield curve, following market developments.

\section{Macro Policy: Do Politics Threaten the Fed's Ability to Backstop the Domain of the Dollar?}

The answer is possibly. The Fed did not extend swaps to some G20 countries (China, India, Indonesia, Russia and Turkey) in 2008 or 2020. Such countries account for a substantial and growing share of the dollar's domain outside the U.S. (Foulis 2015). Some of these countries have friendly relations with the U.S., but others do not. It used to be that the domain of the dollar consisted almost entirely of U.S. allies. Would the Federal Reserve supply $\$ 100$ bills to meet a run on dollar deposits in the Hong Kong special administration region (SAR) or mainland China? 


\section{Conclusions}

Markets have extended the dollar's domain substantially beyond U.S. borders with often surprising results. In myth, the global domain of the dollar is unstable and lucrative; reality is more mundane. In policy, the Federal Reserve has domestic goals, but the dollar's domain gives its policies powerful effects on a large swathe of the global economy. In 2008 and 2020, the Fed minimized the friction between its national control of the dollar and the dollar's broad global role. However, politics may put at risk the Fed's future ability to backstop the dollar's global domain.

Open Access This article is licensed under a Creative Commons Attribution 4.0 International License, which permits use, sharing, adaptation, distribution and reproduction in any medium or format, as long as you give appropriate credit to the original author and the source, provide a link to the Creative Commons licence, and indicate if changes were made. The images or other third party material in this article are included in the article's Creative Commons licence, unless indicated otherwise in a credit line to the material. If material is not included in the article's Creative Commons licence and your intended use is not permitted by statutory regulation or exceeds the permitted use, you will need to obtain permission directly from the copyright holder. To view a copy of this licence, visit http://creativecommons.org/ licenses/by/4.0/.

\section{References}

Aldasoro, I., Ehlers, T., McGuire, P., \& von Peter, G. (2020). Global banks' dollar funding needs and central bank swap lines. BIS Bulletin, 27. https://www.bis.org/publ/bisbull27.pdf Accessed 16 July 2020.

Aliber, R. (1964). The costs and benefits of the U.S. role as a reserve currency country. Quarterly Journal of Economics, 78(3), pp 442-456.

Aliber, R. (1982). The evolution of currency areas: A speculation on monetary history. In: R. Cooper, P. Kenen, J. de Macedo and J. van Ypersele (Eds.), The international monetary system under flexible exchange rates. Global regional and national, essays in hour of Robert Triffin, Cambridge, Massachusetts: Ballinger, pp $147-160$.

Aliber, R. (1980). The integration of the offshore and domestic banking system. Journal of Monetary Economics, 6(4), pp 509-26.

Aliber, R. (2016). The new international money game (7th ed.). Basingstoke, Hampshire: Palgrave Macmillan.

Aliber, R., \& Kindleberger, C. (2015). Manias, panics and crashes (7th ed.). Basingstoke, Hampshire, Palgrave Macmillan.

Avdjiev, S., Bruno, V., Koch, C., \& Shin, H.S. (2019). The dollar exchange rate as a global risk factor: Evidence from investment. IMF Economic Review, 67(1), pp 151-173.

Avdjiev, S., McCauley, R., \& Shin, H.S. (2016). Breaking free of the triple coincidence. Economic Policy, 31(87), pp 409-45.

Avdjiev, S., Eren, E., \& McGuire, P. (2020). Dollar funding costs during the Covid-19 crisis through the lens of the FX swap market. BIS Bulletin, no 1. https://www.bis.org/publ/bisbull01.pdf Accessed 1 April 2020.

Baba, N., McCauley, R., \& Ramaswamy, S. (2009). U.S. dollar money market funds and non-U.S. banks. BIS Quarterly Review, pp 65-81. https://www.bis.org/publ/qtrpdf/r_qt0903g.pdf

Bahaj, S., \& Reis, R. (2018). Central bank swap lines. Bank of England Staff Working Paper No. 741. https:// www.bankofengland.co.uk/-/media/boe/files/working-paper/2018/central-bank-swap-lines.pdf

Bahaj, S., \& Reis, R. (2020). Central bank swap lines during the Covid-19 pandemic. Covid economics, Online only free access, issue 2. http://personal.lse.ac.uk/reisr/papers/20-covicbswaps.pdf Accessed 8 April 2020.

Bank for International Settlements (2020). Statistical release: BIS global liquidity indicators at end-June 2020. www.bis.org/statistics/gli2009.pdf

Bénétrix, A., Lane, P., \& Shambaugh, J. (2015). International currency exposures, valuation effects and the Global Financial Crisis. Journal of International Economics, 96, pp S98-S109. 
Bordo, M., \& McCauley, R. (2019). Triffin: dilemma or myth. IMF Economic Review, 67(4), pp 824-851.

Borio, C., McCauley, R., \& McGuire, P. (2011). Global credit and domestic credit booms. BIS Quarterly Review, pp 43-57. www.bis.org/publ/qtrpdf/r_qt1109f.pdf.

Borio, C., McCauley, R., \& McGuire, P. (2017). FX swaps and forwards. missing global debt? BIS Quarterly Review, pp 37-54. www.bis.org/publ/qtrpdf/r_qt1709e.htm .

Borio, C., McCauley, R., McGuire, P., \& Sushko, V. (2016). Covered interest parity lost. understanding the cross-currency basis. BIS Quarterly Review, pp 45-64. https://www.bis.org/publ/qtrpdf/r_qt1609e.pdf

Burcu, E., Lombardi, M., Mihaljek, D., \& Shin, H.S. (2020). The dollar, bank leverage, and real economic activity. AEA Papers and Proceedings, 110, pp 529-534.

Caballero, R., Farhi, E., \& Gourinchas, P. O. (2017). The safe assets shortage conundrum. Journal of Economic Perspectives, 31(3), pp 29-46.

Cohen, B. (2012). The benefits and costs of an international currency. Open Economies Review, 23, pp 13-31.

Eichengreen, B. (2011). Exorbitant privilege. Oxford: Oxford University Press.

Eichengreen, B., \& Flandreau, M. (2009). The rise and fall of the dollar (or when did the dollar replace sterling as the leading reserve currency?). European Review of Economic History, 13(3), pp $377-411$.

Eichengreen, B., \& Flandreau, M. (2010). The Federal Reserve, the Bank of England and the rise of the dollar as an international currency, 1914-39. BIS Working Papers No. 328. https://www.bis.org/ publ/work328.pdf?noframes $=1$

Eichengreen, B., \& Gros, D. (2020). Post-COVID-19 global currency order. risks and opportunities for the euro. European Parliament, Policy Department for Economic, Scientific and Quality of Life Policies at the request of the Committee on Economic and Monetary Affairs. https://www.europarl.europa.eu/ RegData/etudes/STUD/2020/652751/IPOL_STU(2020)652751_EN.pdf

Eichengreen, B., Mehl, A., \& Chitu, L. (2019). How global currencies work. Princeton: Princeton University Press.

European Commission (2019). Strengthening the international role of the euro: Results of the consultations. Staff Working Document 600, Brussels. https:/ec.europa.eu/info/sites/info/files/ strengthening-international-role-euro-swd-2019_en.pdf Accessed 12 June 2020.

Farhi, E., Gourinchas, P.O., \& Rey, H. (2011). Reforming the International Monetary System. London: Centre for Economic Policy Research. https://voxeu.org/sites/default/files/file/Reforming\%20the\%20International\% 20Monetary\%20System.pdf

Farhi, E., \& Maggiorre, M. (2018). A model of the international monetary system. Quarterly Journal of Economics, 133(1), pp 295-355.

Foulis, P. (2015). The sticky superpower. Economist Special Report. The World Economy. http://www. economist.com/sites/default/files/20151003_world_econ.pdf Accessed 3 October 2020.

Goldberg, L., Kennedy, C. \& Miu, J. (2010). Central bank dollar swap lines and overseas dollar funding costs'. Federal Reserve Bank of New York Staff Reports no 429. https://www.newyorkfed.org/ medialibrary/media/research/staff_reports/sr429.pdf

Gopinath, G., \& Stein, J. (2018). Trade invoicing, bank funding, and central bank reserve holdings. AEA Papers and Proceedings, 108, pp 542-546.

Gourinchas, P.O., \& Rey, H. (2007). From world banker to world venture capitalist. U.S. external adjustment and the exorbitant privilege. In: R. Clarida (Ed.), G-7 current account imbalances. sustainability and adjustment, Chicago: University of Chicago Press, pp 11-55.

Gourinchas, P.O., \& Rey, H. (2014). External adjustment, global imbalances, valuation effects. In: G. Gopinath, E. Helpman and K. Rogoff (Eds.), Handbook of International Economics (vol 4), North Holland, pp 585-646.

He, D., \& McCauley, R. (2012). Eurodollar banking and currency internationalization. BIS Quarterly Review, pp 33-46. https://www.bis.org/publ/qtrpdf/r_qt1206f.pdf

Ilzetzki, E., Reinhart, C., \& Rogoff, K. (2019). Exchange arrangements entering the 21st Century: Which anchor will hold? Quarterly Journal of Economics, 134(2), pp 599-646.

Ito, H., \& McCauley, R. (2019). A key currency view of global imbalances. Journal of International Money and Finance, pp 97-115. https://doi.org/10.1016/j.jimonfin.2019.01.013

Ito, H., \& McCauley, R. (2020). Currency composition of foreign exchange reserves. Journal of International Money and Finance, 102. https://doi.org/10.1016/j.jimonfin.2019.102104

Kindleberger, C. (1965). Balance of payments deficits and the international market for liquidity, Essays in International Finance (no 46). Princeton, NJ: International Finance Section, Princeton University. 
Laster, D., \& McCauley, R. (1994). Making sense of the profits of foreign firms in the United States. Federal Reserve Bank of New York Quarterly Review, 19(2), summer-autumn, pp 44-60.

McCauley, R. (2015). Does the U.S. dollar confer an exorbitant privilege? Journal of International Money and Finance, 57, 1-14. https://doi.org/10.1016/j.jimonfin.2015.06.005.

McCauley, R. (2017). Global bond market spillovers from monetary policy and reserve management. In: A. Ghosh and M. Qureshi (Eds.), From Great Depression to Great Recession. the elusive quest for international policy cooperation. Washington. IMF, pp 147-66. https://www.elibrary.imf.org/view/ IMF071/23159-9781513514277/23159-9781513514277/ch10.xml?redirect=true

McCauley, R. (2020a). The Fed in the corporate bond market in 2020. Boston University Global Development Policy GEGI Working Paper 041. https://www.bu.edu/gdp/2020/08/07/the-fed-in-the-corporatebond-market-in-2020/ Accessed 7 August 2020.

McCauley, R. (2020b). Safe assets and reserve management. In J. Bjorheim (Ed.), Asset management at central banks and monetary authorities (pp. 131-50). Springer Nature: Cham, Switzerland.

McCauley, R., McGuire, P. and Sushko, V. (2015). U.S. monetary policy, leverage and offshore dollar credit. Economic Policy, 30(82), April, pp 187-229. https://academic.oup.com/economicpolicy/issue/ $30 / 82$

McCauley, R., \& Schenk, C. (2020). Central bank swaps then and now: Swaps and dollar liquidity in the 1960s. BIS Working Papers no 851. https://www.bis.org/publ/work851.pdf

McCauley, R., \& Shu, C. (2019). Recent renminbi policy and currency co-movements. Journal of International Money and Finance, 95, pp 444-456.

McKinnon, R. (1969). Private and official international money: The case for the dollar, Princeton Essays in International Finance 74. Princeton, NJ: International Finance Section, Princeton University.

O'Malley, C. (2015). Bonds without borders: A history of the Eurobond market. Chichester, West Sussex: Wiley.

Prasad, E. (2014). The dollar trap. Princeton: Princeton University Press.

Schenk, C. (1998). The origins of the Eurodollar market in London: 1955-1963. Explorations in Economic History, 35(2), pp 221-238.

Swoboda, A. (1968). The euro-dollar Market. an interpretation, Princeton Essays in International Finance 64. Princeton, NJ: International Finance Section, Princeton University.

Tille, C. (2003). The impact of exchange rate movements on U.S. foreign debt, Federal Reserve Bank of New York Current Issues in Economics and Finance, 9(1). https://www.newyorkfed.org/medialibrary/ media/research/current_issues/ci9-1.pdf

Tooze, A. (2018). Crashed. how a decade of financial crises changed the world. New York: Allen Lane.

Triffin, R. (1960). Gold and the dollar crisis. New Haven, CT: Yale University Press.

Volcker, P., \& Feldstein, Mm. (2013). Interview with Paul Volcker. Journal of Economic Perspectives, 27(4), pp 105-120.

Publisher's Note Springer Nature remains neutral with regard to jurisdictional claims in published maps and institutional affiliations. 